る像か？

答 血腫様エコーの説明ではなく, 貯留された血液像 之訂正する。

演題23は, 消化管穿孔発生部位別頻度は十二指腸が最 屯多く, 胃, 結腸の順であり, 遊離ガス像の描出率は胃 穿孔, 十二指腸潰瘍, 結腸穿孔の順で多く, また描出部 位は右横隔膜下が多かった。とのことから腹部単純エッ クス線写真における消化管穿孔時の遊離ガス像の描出率 は高く有用性があるが，乙の描出率は患者の状態にもよ るが撮影上の手技的なものにも左右されると報告した。

有意義な研究発表が多かったが時間的制約もあり, 参 加者個々には明確にできなかったいくつかの閏題点も残 ったように思われた。

撮影 -3

座長 木村金二（富山逓信病院）

\section{4. カーボンシステムの臨床応用についての検討}

三重大学医学部附属病院放射線部

○宮崎幸俊・中西 篤・高田孝広

牧 浩昭・松村佳彦

最近カーボンファイバーの撮影関連具への応用がなさ れて来ている. そこでX線吸収と散乱線特性について検 討を行い, 合せて臨床使用への効果についても検討を行 った。

システム化（グりッドとカセッテ）して使用すると 40 〜 60\%のX線被曝軽減となる. 高コントラスト造影写真 に有効である，画質は撮影条件の改善（管電圧，小焦点， 短時間等）によって向上される，等の結果を得た。

\section{5. 回診用薄型 $\ulcorner$ Carbon cassette $」$ 試作について} 三重大学医学部附属病院中央放射線部

○松村佳彦・宮崎幸俊・牧 浩昭 北野外紀雄・江原 功・中西 篤 高田孝広

回彰用ポータブル撮影の増加に伴ない, 従来のアルミ カセッテでは, 回診用ポータブルの構造上, 収納枚数に 大きな制約があるため, 従来の規格である厚みを $8 \mathrm{~mm}$ 厚に軽減した大角 carbon cassette 老試作した. 実際で の使用より，作業性の改善，収納枚数の增加により，回 診時間の短縮, 患者, 技師, 介助者への被曝量の軽減も はかれ，たわみによる患者への背中への異和感の軽減も はかれた。また，臨床上の画質低下む見い出されなかっ た。

質問 カーボンカセッテの久点として(きれつ, 割れ) が言われるが貴院での試作品では落下テスト等を施行し たかどうか?
その結果はどうであったか。（白鳥）

答 cassette の搬送は belt conveyer で一括してやっ ているので，特に落下テストは行なわれなかった。

普通の状態での普通の衝撃落下では全く異常は認めら れなかった。

\section{6. 陽極側 $\mathbf{X}$ 線錐利用の検討一胃 $\mathbf{X}$ 線検查への応用一} 大垣古民病院放射線科

○鶴田初男・遠藤斗紀雄・川上文浩 高木 等・岩崎浩康・坂野信也 茂木正義・金森勇雄

1） X線管の長軸方向の焦点幅を実測した所，陽極側 に近づくに従って小さくなり, 理論值と良く相関した. 2）より小さい焦点を利用する目的で，管球に角度を付 けて陽極側線錐を利用しても，公称照射野までの範囲で は臨床上の写真濃度に影響はなかった。 3) MTF の評 価においてす, 焦点が小さい程, すなわち陽極側に近い 線錐を利用する程良くなった。4）胃X線検査のように, ぞちらかと言えば写真上で，下半分に横線の要素が多く， かつ下半分に病変の多い検査では，足側に陽極を配し， しかも角度を付けるととにより，さらに鮮鋭度の良い写 真が得られた。

\section{7. 各種 $X$ 線撮影用支持装置の考案 $\mathrm{X}$ 線検查時におけ} る患者心理について一第 2 報「固定」一 名古屋大学医学部附属病院分院放射線科 ○堀部広恵・堀部泰樹

X線検査の中で, 患者整位, 固定, 再現性には最毛多 くの時間を必要とするままた私達の調査においてもX線 検査受彰の患者（幼览）には大別して次の 2 種の患者層 に気付いた． 1 ．患者（幼児）自身が納得している場合 (自己認識型) あるいは何手理解してないが拹力的な場 合 (協力型). 2 . 強制的にのみ検查が遂行される場合 (強制型)，私達は各種支持装置の開発に当り，前述の型 態を充分に考慮し, 目的検查部位の正確な情報の確保, 迅速な情報取得, 正確な再現性等診断領域へのアプロー チと装置等に接する異和感の除去等患者サービスへの向 上の両面を持ち合わせた装置の考案を試み, 多くの成果 と各種の問題点を知見したので報告する.

質問 1 . 胸部固定具の使用対象年鈴は何歳か。 2 . 小児胸部立位撮影時の頭部固定の配慮をされているか. (宮本)

答 (1) 小児の対象年秢は0〜3歳ぐらいとするが，立 位撮影では，映画， animation が理解可能年齢は $2 \sim 3$ 祡 が対象となる。(2) 特に頭部国定はしないが，映画が目 の位置にくるようにするか，親が演技をするととで，充 